\title{
Perhedaan Status Besi Bayi Normal yang Mendapat Air Susu Ihu Eksklusif dengan Susu Formula Standar
}

\author{
Henne Giyantini, Ponpon Idjradinata, Herry Garna \\ Departemen Ilmu Kesehatan Anak, Fakultas Kedokteran, Universitas Padjadjaran, \\ Rumah Sakit Dr. Hasan Sadikin, Bandung
}

\begin{abstract}
Latar Belakang. Anemia defisiensi besi (ADB) pada anak dapat menyebabkan gangguan kognitif, psikomotor, dan tingkah laku menetap meskipun anemia dikoreksi. Pada usia 4-6 bulan, cadangan besi menurun, pertumbuhan cepat dan asupan besi rendah menyebabkan ADB.

Tujuan. Menganalisis perbedaan status besi bayi yang mendapat ASI eksklusif dengan susu formula standar (SFS) dan mengetahui waktu pemberian suplemen besi yang tepat.

Metode. Penelitian analitik potong-lintang di RSUD Ujungberung dan Cibabat serta RSKIA Astanaanyar Bandung periode Juni-Juli 2012, pada bayi 4, 6 dan 9 bulan, lahir cukup bulan, berat lahir $>2.500$ g, sehat dan mendapat ASI eksklusif atau SFS. Dilakukan pemeriksaan Hb, MCV, Fe serum, TIBC, dan feritin serum. Uji Mann-Whitney dilakukan untuk mengetahui perbedaan status besi.

Hasil. Subjek 60 bayi. Pada kelompok ASI eksklusif dan SFS 4, 6, dan 9 bulan Hb berturut-turut 10,57; 10,86; 9,64 dan 10,77; 11,22; 11,74 g/dL; TIBC 294,3; 265,4; 339 dan 297,5; 268; 317,8 $\mu \mathrm{g} / \mathrm{dL}$; MCV 70,$3 ; 72,9 ; 62,89$ dan 77,$57 ; 72,82 ; 73,39 \mathrm{fl}$; serta feritin serum 81,$1 ; 131,7 ; 26,5$ dan 120,$2 ; 56 ; 45,9$ $\mu \mathrm{g} / \mathrm{L}$ berbeda bermakna ( $\mathrm{p}=0,017 ; \mathrm{p}=0,049 ; \mathrm{p}<0,001 ; \mathrm{p}<0,001)$. Fe serum 44,7; 43,1; 26,4 $\mu \mathrm{g} / \mathrm{dL}$ dan 33,9; 35,9; 40,8 $\mu \mathrm{g} / \mathrm{dL}$ tidak bermakna ( $\mathrm{p}=0,202)$. Bayi yang mengalami DB dan ADB pada usia 9 bulan lebih banyak terjadi pada bayi yang mendapat ASI eksklusif ( $p=0,020)$. Enam dari 10 bayi mengalami DB dan ADB pada usia 4 bulan pada kedua kelompok.

Kesimpulan. Status besi bayi normal yang mendapat ASI eksklusif lebih rendah daripada bayi yang mendapat SFS. Rekomendasi pemberian suplemen besi mulai usia 4 bulan, perlu ditinjau ulang.

Sari Pediatri 2013;15(2):127-32.
\end{abstract}

Kata kunci: besi, anemia, ASI, formula

Alamat korespondensi:

Dr. Henne Giyantini, Sp.A. Departemen Ilmu Kesehatan Anak, Fakultas Kedokteran UNPAD/RSHS. Jl. Pasteur 38 Bandung 40163, Telp. (022) 2035957, Fax. (022) 2034426. E-mail: giyantini@yahoo.com

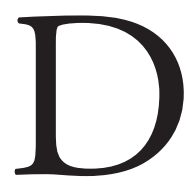

efisiensi besi (DB) merupakan penyebab tersering anemia pada bayi dan anak di dunia. Prevalensi DB di negara berkembang masih tinggi, disebabkan kemampuan ekonomi yang terbatas. ${ }^{1,2-8}$ Di Cina tahun 
2001, angka kejadian DB dan anemia defisiensi besi (ADB) $44,7 \%$ dan $20,8 \%$ pada bayi usia $<12$ bulan. ${ }^{9}$ Berdasarkan Survei Kesehatan Rumah Tangga (SKRT) di Indonesia tahun 2004, ADB terjadi pada 39\% balita. ${ }^{10}$ Penelitian di Indonesia, dilaporkan ADB pada bayi yang diberi air susu ibu (ASI) $18,9 \%$, bayi usia 4-6 bulan 6\%, dan $9-12$ bulan $65 \% .{ }^{11}$

Pada DB tidak hanya hantaran oksigen ke jaringan yang mengalami gangguan, tetapi juga menyebabkan gangguan pertumbuhan, fungsi kekebalan, kognisi, psikomotor, dan tingkah laku. ${ }^{12}$ Besi diperlukan pada fungsi oligodendrosit normal dan mielinisasi, sintesis neurotransmiter, dan metabolisme energi pada otak. ${ }^{13-16}$ Defisiensi besi pada otak terjadi pada saat hemoglobin (Hb) masih dalam kadar normal. Perubahan tersebut menetap dan tidak akan kembali normal. Pada bayi, gangguan akibat DB menjadi hal penting karena perkembangan otak yang cepat terjadi bertepatan dengan usia saat prevalensi $\mathrm{ADB}$ paling tinggi. ${ }^{13-15}$

Beberapa penelitian menunjukkan ADB kronik pada saat bayi menyebabkan gangguan tingkah laku dibandingkan dengan bayi anemia yang terkoreksi sebelum usia 2 tahun dan bayi yang tidak ADB. Pemberian suplemen besi dapat memperbaiki perkembangan psikomotor, tetapi tidak terjadi pada perkembangan kognisi dan tingkah laku. ${ }^{13,16}$ Penelitian kohort di Beijing ditunjukkan status besi bayi yang mendapat SFS lebih rendah daripada bayi yang mendapat ASI eksklusif dan bayi laki-laki memiliki risiko anemia lebih besar daripada perempuan. ${ }^{17}$

Tujuan penelitian ini untuk mengetahui perbedaan status besi bayi normal yang mendapat ASI eksklusif dengan SFS dan untuk mengetahui mulai usia berapa DB terjadi.

\section{Metode}

Telah dilakukan penelitian potong lintang di wilayah kerja RSUD Ujungberung dan Cibabat, serta RSKIA Astanaanyar periode Juni-Juli 2012. Subjek penelitian terdiri dari bayi usia 4, 6, 9 bulan, lahir cukup bulan, berat lahir $>2.500 \mathrm{~g}$, sehat pada saat pemeriksaan dan mendapat ASI eksklusif atau SFS. Jumlah subjek 60 orang, terbagi dalam 6 kelompok yang terdiri dari 10 orang tiap kelompok. Subjek yang memenuhi kriteria inklusi diberikan penjelasan mengenai penelitian kepada orangtua dan setelah menyetujui diminta untuk menandatangani lembar persetujuan/informed consent.
Subjek dieksklusi apabila mendapat suplemen besi. Subjek kemudian dilakukan pemeriksaan $\mathrm{Hb}, \mathrm{MCV}$, Fe serum, TIBC, dan feritin serum untuk menilai status besi, CRP untuk menyingkirkan infeksi, serta recall makanan 24 jam selama 3 hari berturut-turut. Analisis data menggunakan uji Anova, Kruskall Wallis, chi-square, dan Mann Whitney dengan kemaknaan berdasarkan nilai $\mathrm{p}<0,05$.

\section{Hasil}

Karakteristik orangtua subjek penelitian meliputi pendidikan ayah, pendidikan ibu, pekerjaan ayah, pekerjaan ibu, dan penghasilan keluarga tertera pada Tabel 1. Pada karakteristik orangtua subjek penelitian tidak terdapat perbedaan bermakna kecuali pekerjaan ibu $(\mathrm{p}=0,020)$ antara kelompok ASI eksklusif dan SFS.

Karakteristik umum subjek penelitian meliputi jenis kelamin, berat badan lahir, berat badan saat dilakukan pemeriksaan, panjang badan dan lingkar kepala dan kadar CRP tertera pada Tabel 2. Karakteristik umum subjek penelitian menunjukkan bahwa status gizi subjek dalam batas normal dan saat pemeriksaan subjek dalam kondisi sehat yang ditunjukkan pada nilai CRP yang normal pada semua subjek.

Perbandingan jumlah asupan besi yang berasal dari makanan rata-rata per hari antara bayi yang mendapat ASI eksklusif dan SFS tertera pada Tabel 3. Terdapat perbedaan jumlah asupan besi yang berasal dari makanan rata-rata per hari pada setiap kelompok usia 6 dan 9 bulan antara bayi yang mendapat ASI eksklusif dan SFS ( $\mathrm{p}=0,034 ; \mathrm{p}<0,001)$. Kandungan besi pada SFS yang digunakan oleh subjek berkisar antara 3,3-8 $\mathrm{mg} / \mathrm{L}$.

Hasil pemeriksaan kadar Hb, MCV, Fe serum, TIBC, feritin serum, CRP dan perhitungan saturasi transferin pada semua subjek penelitian tertera pada Tabel 4. Terdapat perbedaan bermakna $\mathrm{Hb}, \mathrm{MCV}$, TIBC, dan feritin ( $\mathrm{p}=0,017 ; \mathrm{p}<0,001 ; \mathrm{p}=0,049$; $\mathrm{p}=0,003)$ antara kelompok yang mendapat ASI eksklusif dan SFS.

Perbandingan jumlah DB dan ADB pada bayi yang mendapat ASI eksklusif dan SFS tertera pada Tabel 5.

Terdapat perbedaan bermakna $(\mathrm{p}=0,020)$ jumlah ADB dan DB pada usia 9 bulan tetapi tidak bermakna pada usia 4 dan 6 bulan (Tabel 5). 
Henne Giyantini dkk: Perbedaan status besi bayi normal yang mendapat ASI eksklusif dengan susu formula standar

Tabel 1. Perbandingan karakteristik orangtua bayi yang mendapat ASI eksklusif dan SFS

\begin{tabular}{|c|c|c|c|}
\hline \multirow{2}{*}{ Karakteristik } & \multicolumn{2}{|c|}{ Kelompok } & \multirow[t]{2}{*}{$\mathrm{p}^{*}$} \\
\hline & ASI Eksklusif $(\mathrm{n}=30)$ & SFS $(n=30)$ & \\
\hline \multicolumn{4}{|l|}{ Pendidikan ayah } \\
\hline SD & 5 & 2 & 0,502 \\
\hline SMP & 14 & 13 & \\
\hline SMA & 9 & 13 & \\
\hline Sarjana & 2 & 2 & \\
\hline \multicolumn{4}{|l|}{ Pendidikan ibu } \\
\hline SD & 6 & 5 & 0,718 \\
\hline SMP & 13 & 11 & \\
\hline SMA & 10 & 11 & \\
\hline Sarjana & 1 & 3 & \\
\hline \multicolumn{4}{|l|}{ Pekerjaan ayah } \\
\hline Pegawai swasta & 5 & 6 & 0,858 \\
\hline Wiraswasta & 11 & 10 & \\
\hline Buruh & 12 & 10 & \\
\hline PNS & 1 & 1 & \\
\hline Lainnya & 1 & 3 & \\
\hline \multicolumn{4}{|l|}{ Pekerjaan ibu } \\
\hline IRT & 28 & 21 & 0,020 \\
\hline Bekerja & 2 & 9 & \\
\hline \multicolumn{4}{|c|}{$\begin{array}{l}\text { Penghasilan keluarga } \\
\text { (rupiah) }\end{array}$} \\
\hline$<1$ juta & 1 & 2 & 0,461 \\
\hline $1-1,5$ juta & 20 & 14 & \\
\hline $1,5-3$ juta & 8 & 13 & \\
\hline$>3$ juta & 1 & 1 & \\
\hline
\end{tabular}

Tabel 2. Perbandingan karakteristik umum subjek penelitian antara bayi ASI eksklusif dan SFS

\begin{tabular}{lcccccc}
\hline Karakteristik & \multicolumn{2}{c}{ 4 bulan } & \multicolumn{2}{c}{ 6 bulan } & \multicolumn{2}{c}{9 bulan } \\
\cline { 2 - 6 } & ASI (n=10) & SFS $(\mathrm{n}=10)$ & ASI $(\mathrm{n}=10)$ & SFS $(\mathrm{n}=10)$ & ASI $(\mathrm{n}=10)$ & SFS $(\mathrm{n}=10)$ \\
\hline Jenis kelamin & & & & & & \\
$\quad$ Laki-laki & 6 & 7 & 4 & 8 & 9 & 8 \\
$\quad$ Perempuan & 4 & 3 & 6 & 2 & 1 & 2 \\
BB lahir (kg) & & & & & & \\
$\quad$ Rerata & $2,95(0,33)$ & $2,91(0,40)$ & $3,03(0,33)$ & $3,02(0,28)$ & $3,16(0,40)$ & $3,09(0,34)$ \\
$\quad$ Rentang & $2,6-3,5$ & $2,5-3,8$ & $2,5-3,5$ & $2,6-3,5$ & $2,5-3,9$ & $2,5-3,5$ \\
BB (kg) & & & & & & \\
$\quad$ Rerata & $5,92(0,56)$ & $5,69(0,57)$ & $6,95(0,60)$ & $7,12(0,57)$ & $8,72(0,48)$ & $8,37(0,60)$ \\
$\quad$ Rentang & $5,4-7,0$ & $6,0-8,4$ & $6,2-7,6$ & $6,0-8,4$ & $8,0-9,5$ & $7,6-9,5$ \\
PB (cm) & & & & & & \\
$\quad$ Rerata & $57,9(0,86)$ & $58,1(1,03)$ & $61,8(1,29)$ & $62,0(1,42)$ & $70,6(2,62)$ & $66,3(2,81)$ \\
$\quad$ Rentang & $57,0-59,0$ & $57,0-59,5$ & $60,0-63,0$ & $60,0-64,0$ & $65,0-74,0$ & $64,0-72,0$ \\
LK (cm) & & & & & & \\
$\quad$ Rerata & $40,5(0,76)$ & $39,2(1,03)$ & $43,0(1,15)$ & $43,7(0,80)$ & $45,1(1,18)$ & $42,5(1,57)$ \\
$\quad$ Rentang & $39,5-41,5$ & $38,0-41,0$ & $41,0-44,5$ & $42,0-44,5$ & $43,5-47,0$ & $41,0-46,5$ \\
CRP (mg/dL) & & & & & & \\
$\quad$ Rerata & $0,31(0,30)$ & $0,37(0,2)$ & $0,27(0,19)$ & $0,39(0,28)$ & $0,26(0,21)$ & $0,51(0,80)$ \\
$\quad$ Rentang & $0,12-0,98$ & $0,14-0,69$ & $0,11-0,68$ & $0,11-0,98$ & $0,13-0,68$ & $0,03-2,71$ \\
\hline
\end{tabular}

Keterangan: nilai p berdasarkan uji Kruskal-Wallis 
Tabel 3. Perbandingan jumlah asupan besi yang berasal dari makanan rata-rata per hari $(\mathrm{mg})$

\begin{tabular}{|c|c|c|c|c|c|c|}
\hline \multirow{2}{*}{ Fe Makanan } & \multicolumn{2}{|c|}{6 bulan } & \multirow[b]{2}{*}{$\mathrm{p}$} & \multicolumn{2}{|c|}{9 bulan } & \multirow[b]{2}{*}{$\mathrm{p}$} \\
\hline & ASI $(n=10)$ & SFS $(n=10)$ & & ASI $(n=10)$ & SFS $(n=10)$ & \\
\hline Median & 2,96 & 2,79 & 0,034 & 2,38 & 3,99 & $<0,001$ \\
\hline Rentang & $1,15-15,8$ & $0,17-9,20$ & & $0,89-8,80$ & $1,2-11,9$ & \\
\hline
\end{tabular}

Keterangan: nilai P berdasarkan uji Mann-Whitney

Tabel 4. Perbandingan hasil pemeriksaan laboratorium

\begin{tabular}{|c|c|c|c|c|c|c|c|}
\hline \multirow{2}{*}{$\begin{array}{l}\text { Parameter } \\
\text { laboratorium }\end{array}$} & \multicolumn{3}{|c|}{ ASI eksklusif } & \multicolumn{3}{|c|}{ Susu formula standar } & \multirow[b]{2}{*}{$\mathrm{p}^{*}$} \\
\hline & $\begin{array}{l}4 \text { bulan } \\
(\mathrm{n}=10)\end{array}$ & $\begin{array}{c}6 \text { bulan } \\
(\mathrm{n}=10)\end{array}$ & $\begin{array}{c}9 \text { bulan } \\
(\mathrm{n}=10)\end{array}$ & $\begin{array}{l}4 \text { bulan } \\
(\mathrm{n}=10)\end{array}$ & $\begin{array}{c}6 \text { bulan } \\
(\mathrm{n}=10)\end{array}$ & $\begin{array}{c}9 \text { bulan } \\
(\mathrm{n}=10)\end{array}$ & \\
\hline \multicolumn{8}{|l|}{$\mathrm{Hb}(\mathrm{g} / \mathrm{dL})$} \\
\hline Rerata & $10,57(0,95)$ & $10,86(0,82)$ & $9,64(1,26)$ & $10,77(1,14)$ & $11,22(1,03)$ & $11,17(1,01)$ & 0,017 \\
\hline Rentang & $9,4-12,1$ & $9,7-12,4$ & $9,7-12,4$ & $8,6-12,5$ & $9,4-12,8$ & $9,6-12,5$ & \\
\hline \multicolumn{8}{|l|}{ MCV (fL) } \\
\hline Rerata & $70,3(8,17)$ & $72,9(5,99)$ & $62,89(6,62)$ & $77,57(8,40)$ & $72,82(4,17)$ & $73,39(5,54)$ & $<0,001$ \\
\hline Rentang & $59,3-86,0$ & $61,8-81,0$ & $53,3-70,8$ & $66,2-91,4$ & $66,1-80,0$ & $64,8-79,8$ & \\
\hline \multicolumn{8}{|c|}{ Fe serum $(\mu \mathrm{g} / \mathrm{dL})$} \\
\hline Rerata & $44,7(20,79)$ & $43,1(24,1)$ & $26,4(12,11)$ & $33,9(10,94)$ & $35,9(16,48)$ & $40,8(19,93)$ & 0,202 \\
\hline Rentang & $23-81$ & $11-95$ & $17-57$ & $15-48$ & $19-73$ & $22-77$ & \\
\hline \multicolumn{8}{|l|}{ TIBC $(\mu \mathrm{g} / \mathrm{dL})$} \\
\hline Rerata & $294,3(77,2)$ & $265,4(32,68)$ & $339(68,16)$ & $297,5(36,69)$ & $268(56,8)$ & $317,8(63,23)$ & 0,049 \\
\hline Rentang & $182-428$ & $222-319$ & $270-445$ & $224-330$ & $141-325$ & $234-432$ & \\
\hline \multicolumn{8}{|l|}{ Saturasi } \\
\hline \multicolumn{8}{|l|}{ Transferin (\%) } \\
\hline Rerata & $18,4(10,55)$ & $11,49(3,95)$ & $16,69(10,68)$ & $13,72(5,77)$ & $8,23(4,49)$ & $12,99(6,37)$ & 0,051 \\
\hline Rentang & $8,75-44,5$ & $4,9-18,75$ & $4,33-42,0$ & $7,38-22,8$ & $4,12-18,9$ & $6,94-25,9$ & \\
\hline \multicolumn{8}{|l|}{ Feritin $(\mu \mathrm{g} / \mathrm{L})$} \\
\hline Rerata & $81,1(57,77)$ & $131,7(120,58)$ & $26,5(27,88)$ & $120,2(73,19)$ & $56(29,64)$ & $45,9(31,88)$ & $<0,001$ \\
\hline Rentang & $12-181$ & $14-446$ & $4-96$ & $36-286$ & $16-98$ & $8-95$ & \\
\hline
\end{tabular}

Keterangan: *nilai p berdasarkan penghitungan ANOVA

Tabel 5. Perbandingan jumlah defisiensi besi dan ADB

\begin{tabular}{lccccc}
\hline Usia (bulan) & ASI/SFS & Anemia & Defisiensi Besi & Normal & $\mathrm{p}$ \\
\hline 4 & ASI & 5 & 1 & 4 & 0,801 \\
& SFS & 4 & 2 & 4 & \\
6 & ASI & 4 & 2 & 4 & 0,842 \\
& SFS & 3 & 3 & 4 & \\
9 & ASI & 9 & 0 & 1 & 0,020 \\
& SFS & 3 & 3 & 4 & \\
\hline
\end{tabular}

Keterangan: *nilai p berdasarkan uji Chi-kuadrat

\section{Pembahasan}

Berdasarkan karakteristik sosio-ekonomi orangtua bayi yang mendapat ASI eksklusif dan SFS tidak berbeda bermakna sehingga faktor perancu tersebut pada analisis perbedaan status besi dapat diabaikan.
Pada pemeriksaan laboratorium kadar $\mathrm{Hb}$ cenderung menurun pada kelompok ASI eksklusif, sedangkan pada kelompok SFS cenderung meningkat. Nilai MCV cenderung menurun pada kedua kelompok, tetapi lebih tinggi pada kelompok SFS. Kedua kelompok memiliki nilai TIBC cenderung meningkat pada usia 9 
bulan. Feritin serum pada kedua kelompok cenderung menurun, pada usia 9 bulan kadarnya lebih rendah pada kelompok ASI eksklusif.

Sebuah penelitian menunjukkan penurunan kadar $\mathrm{Hb}$ setelah usia 6 bulan pada bayi yang masih mendapatkan ASI dibandingkan dengan saat usia bayi tersebut 4 dan 6 bulan. ${ }^{18}$ Begitu pula penelitian yang dilakukan Raj $\mathrm{dkk}^{19}$ pada bayi yang mendapat ASI eksklusif dan diikuti hingga usia 6 bulan menunjukkan bahwa bayi tidak menunjukkan DB pada usia 6 bulan. Berdasarkan anjuran dari AAP, kebutuhan besi usia 4-6 bulan $0,27 \mathrm{mg}$, sedangkan pada usia 6 bulan hingga 1 tahun pada bayi lahir cukup bulan $11 \mathrm{mg}$ per hari. ${ }^{18}$ Pada penelitian kami, jumlah asupan besi yang berasal dari makanan pendamping ASI dan SFS rata-rata per hari berbeda bermakna. Begitu pula kandungan besi pada SFS yang digunakan oleh subjek 3,3-8 $\mathrm{mg} / \mathrm{L}$, nilai tersebut lebih rendah daripada rekomendasi AAP tahun 1999, yaitu $10-12 \mathrm{mg} / \mathrm{L}$ sehingga ADB pada bayi yang mendapat SFS dapat disebabkan oleh rendahnya kadar besi pada SFS yang digunakan.

Defisiensi besi dan ADB pada usia 4 dan 6 bulan tidak berbeda bermakna antara bayi yang mendapat ASI ekslusif dengan bayi yang mendapat SFS. Faktor yang dapat memengaruhi status besi bayi adalah status besi ibu sebelum dan saat hamil, usia kehamilan, berat lahir, waktu pemotongan tali pusat, penambahan berat badan dan asupan makanan. Perbedaan yang tidak bermakna pada jumlah bayi yang mengalami DB dan ADB antara bayi yang mendapat ASI eksklusif dan SFS mungkin dipengaruhi oleh status besi ibu sebelum dan saat hamil yang datanya tidak terdapat pada penelitian kami. Faktor lain yaitu usia kehamilan, berat lahir, waktu pemotongan tali pusat yang dapat memengaruhi status besi ini telah disingkirkan melalui kriteria inklusi. Penambahan berat badan yang dapat memengaruhi status besi ini setelah dilakukan uji statistik tidak berbeda bermakna antara bayi yang mendapat ASI eksklusif dan SFS.

Pada usia 9 bulan, jumlah bayi yang mengalami DB dan ADB berbeda bermakna, di antara beberapa faktor yang dapat memengaruhi status besi seperti yang telah disebutkan sebelumnya maka faktor yang mungkin dapat menyebabkan perbedaan yang bermakna adalah asupan besi dari makanan pendamping. Pada penelitian kami, asupan besi rata-rata per hari yang berasal dari makanan pendamping pada usia 9 bulan lebih besar pada bayi yang mendapat SFS.
Penelitian kami menunjukkan bahwa pada usia 4 bulan bayi yang mendapat ASI eksklusif maupun bayi yang mendapat SFS telah mengalami ADB sehingga pemberian suplemen besi mungkin harus mulai diberikan sebelum usia 3 bulan, walaupun hal tersebut memerlukan penelitian lebih lanjut. Selain diberikannya suplemen besi sebagai pencegahan terjadinya defisiensi besi pada bayi, diperlukan kerjasama dengan dokter kandungan dan bidan untuk pemberian suplemen besi pada ibu hamil.

Penelitian kami memiliki beberapa keterbatasan, di antaranya penelitian kami tidak dilakukan secara kohort mengikuti status besinya sejak lahir sampai usia 9 bulan sehingga dapat memengaruhi hasil. Status ibu saat hamil dapat memengaruhi status besi bayi, sedangkan pada penelitian kami tidak ada data status besi ibu bayi.

\section{Kesimpulan}

Status besi bayi normal yang mendapat ASI eksklusif lebih rendah daripada bayi yang mendapat SFS. Rekomendasi pemberian suplemen besi mulai usia 4 bulan, perlu ditinjau ulang.

\section{Daftar pustaka}

1. Chang S, Wang L, Wang Y, Brouwer ID, Kok FJ, Lozoff $\mathrm{B}$ dkk. Iron deficiency anemia in infancy and social emotional development in preschool aged Chinese children. Pediatrics 2011;127:927-33.

2. Glader B. Iron deficiency anemia. Dalam: Kliegman RM, Behrman RE, Jenson HB, Santon BF, penyunting. Nelson textbook of pediatrics. Edisi ke-18. Philadelphia: Saunders; 2007.h.2014-7.

3. Killip S, Bennett JM, Chambers MD. Iron deficiency anemia. Am Fam Physician 2007;75:671-8.

4. McCann JC, Ames BN. An overview of evidence for a causal relation between iron deficiency during development and deficits in cognitive or behavioral function. Am J Clin Nutr 2007;85:931-45.

5. Lanzkowsky P. Manual of pediatrics hematology and oncology. Edisi ke-4. Burlington: Elsevier; 2005.

6. WHO. Iron deficiency: assessment, prevention and control. Edisi ke-1. Geneva: WHO publications; 2001.

7. WHO/CDC. Assesing the iron status of populations. 
Edisi ke-1. Geneva: WHO publications; 2004.

8. Wu AC, Lesperance L, Bernstein H. Screening for iron deficiency. Pediatr Rev 2002;23:171-7.

9. Zhu Y, Liao Q. Prevalence of iron deficiency in children aged 7 months to 7 years in China. Zhonghua Er ke Za Zhi 2004;42:886-91.

10. Departemen Kesehatan Republik Indonesia. Riset Kesehatan dasar 2007. Jakarta: Badan Penelitian dan Pengembangan Kesehatan; 2008.

11. Ratnadi IGAA, Soetjiningsih. Iron status in breast-fed infants. Paediatr Indones 2001;41:191-6.

12. Ghosh K. Non haematological effects of iron deficiency - A perspective. Indian J Med Sci 2006;60:30-7.

13. Yadav D, Chandra J. Iron deficiency: beyond Anemia. Indian J Pediatr 2011;78:65-72.

14. Beard J. Recent evidence from human and animal studies regarding iron status and infant development. J Nutr 2007; 137:524-30.

15. Beard J. Why iron deficiency is important in infant development. J Nutr 2008;138:253-6.

16. Szajewska H, Ruszczynski M, Chmielewska A. Effects of iron supplementation in nonanemic pregnant women, infants, and young children on the mental performance and psychomotor development of children: a systematic review of randomized controlled trials. Am J Clin Nutr 2010;91:1684-90.

17. Yu-hua G, Cheng-ye J, Xiu-xia Z, Jin-ping S, Rui H. Correlation of 4-month infant feeding modes with their growth and iron status in Beijing. Chin Med J 2008;121:392-8.

18. Derr JM, Guerrero ML, Altaye M, Gallegos HO, Palacios GR, Morrow AL. Risk of infant anemia is associated with exclusively breast-feeding and maternal anemia in a mexican cohort. J Nutr 2006;136:452-8.

19. Raj S, Faridi MMA, Rusia U, Singh O. A prospective study of iron status in exclusively breastfed term infants up to 6 months of age. International Breastfeeding J 2008;3:1-7. 